\title{
Work Skills Factor for Mechanical Engineering Students of Vocational High School
}

\section{Suryo Hartanto, Sri Langgeng Ratnasari, and Zaenal Arifin}

Riau Kepulauan University, Indonesia

\section{Abstract}

Vocational education graduates are indicated having the very low competence and cannot meet the expectations of the work requirement, it has an impact on lower absorption of employment for vocational education regionally and nationally. In order to meet the needs of the job competence, vocational students should have good work skills. The purpose of this study was to determine the need for skills of work consisting of soft skills and hard skills for vocational education students of mechanical engineering. This research was quantitative descriptive analysis conducted by using Dacum approach. The sample of the study consisted of 100 respondents, comprising industry practitioners, vocational education practitioners, and relevant expert of

Corresponding Author: Suryo Hartanto

suryo@fkip.unrika.ac.id

Received: 18 January 2019

Accepted: 24 March 2019

Published: 31 March 2019

Publishing services provided by Knowledge E

(c) Suryo Hartanto et al. This article is distributed under the terms of the Creative Commons Attribution License, which permits unrestricted use and redistribution provided that the original author and source are credited.

Selection and Peer-review under the responsibility of the ICEST 2018 Conference Committee.

\section{G OPEN ACCESS} vocational education in engineering. Based on the analysis, there are 27 items of soft skills and 67 items of hard skills recommended for works for vocational students. Based on the analysis, the findings will be used as a reference for developing a leanbased learning model to improve the work skills of vocational students of mechanical engineering.

Keywords: Need and analysis, Work Skills, soft skills, hard skills

\section{Introduction}

Vocational education is organized as an effort to prepare individuals in reaching expected competency skills, in order to sustain the life of the individual, the workplace, and develop a career in the future, [5; 9; 24]. Graduates of Vocational High School should be addressed as graduates who are ready to work, intelligent, have a competitive advantage, comparative and strong character as a working professional, so that the mastering of hard skills and soft skills must be covered very well to be excellent and better quality graduates in facing the world competition of work. Hard skills must be balanced with soft skills, and soft skills have a tendency as a decisive factor in the recruitment process [8]. With the vocational schools, employment could be provided with good; however, the level of employment absorption of graduates of Vocational High School is not balanced with the condition of the hard skills and soft skills possessed 
by employees graduated from Vocational High School. The absorption of employment nationally for Vocational Senior High Schools (SMK) are 10.87\%, lower than high School graduates who are at $20.52 \%$, for Junior high school is to $18.16 \%$ even for elementary school levels is far greater for $42.23 \%$, which means there are a lot of unemployment and high employment absorption differences between graduates of the education levels. For example, one of the provinces in Indonesia, Riau Islands, has been carrying out development with a complete infrastructure in several areas: agriculture, marine and industrial. Indonesian Central Bureau of Statistics [4], in accordance with the engine works, the number of workers absorbed in the field of industry of manufacturing and machining in Riau Islands was $41.20 \%$. The majority of the industry is located in Batam, but the uptake of its workforce is still very low. An important issue must be resolved. It should be with great potential that can be used to resolve such issues, especially vocational schools in order to meet the needs of the industry, the world of work and increasing the number of employment absorption of the vocational education.

Learning at SMK has not approached aspects of hard skills and soft skills comprehensively and thoroughly so that graduates are not quite enough to have hard skills and soft skills, that industry needs. Developing hard skills and soft skills directly integrated with the work process form the experience of hard skills and soft skills in the learning process directly. [9;12;15]. SMK can improve the competency skills through appropriate learning strategies to fit the needs of work, improving knowledge, attitudes, skills, and values that are needed for the job. Students should be provided with the knowledge, skills, attitudes, and values necessary in a real working environment.[16; 9] integrated learning with the world of work, provide experience to students and build bridges between school education with the professional working world. Learning that is integrated with real working world provides a huge benefit in the acquisition of vocational competence. [3; 22], Integration with the world of work is a form of environmental role to change the competence of vocational students achieving sustainable development.

The learning system should be established in accordance with the needs of the community, this analysis is an important step to map the special needs of work skills in the mechanical engineering department of SMK to be used as a reference in composing the learning. The aim of this research is to determine the extent of needs of soft skills and hard skills for SMK students as an effort to develop work competence skills of students majoring mechanical engineering. 


\section{Literature Review}

The dynamic changes in the industry need to be observed so that learning process that is similar to the industry standard is necessary. Learning is a process toward change. Learning is the process of Obtaining mastery, knowledge, habits, which is Obtained from the process of learning,[23]. The knowledge that is Obtained in the form of facts, concepts, procedures, and principles of students characteristic can do so by involving interaction with the external environment that can change someone's behavior,[23; 18; 21]. Vocational education must have the principle of change in accordance with the needs of society and technology. [16], the second proposition, "Effective Vocational training can only be given where the training jobs are carried on in the same way with the same operations, the same tools and the same machines as in the occupation itself". Vocational education can produce competent workforce should meet these standards. Vocational education as one vehicle to prepare students for the world of work must be future-oriented. (Adrian, 2005), socialize people into attitudes appropriate for the world of work, orientate people to understand the world of employment and to prepare for the choices and transition they will have to make on entering it, prepare them with specific skills and knowledge to apply in a direct way after entering employment.

Appropriate learning is integrating it with the industry. The main principle in the industry is to achieve efficiency and high productivity. It was implemented by way of applying Lean Manufacturing. Lean is a production system that claims to create learning organizations through continuous improvements, [10;2]. [25], The Five Primary Elements for lean manufacturing are (1) Manufacturing Flow, (2) Organization, (3) Process Control, (4) Metrics, and (5) Logistics. Lean manufacturing is a concept and principles used in the company and the production process to maximize the work to achieve the maximum benefit by applying the five principles with no separation. [25],"Lean manufacturing, is primarily focused on designing a robust production operation that is responsive, flexible, predictable, and consistent. [11]," it is called Lean because, in the end, the process, it can run: Using less material, requiring less investment, Using less inventory, Consuming less space and, using fewer people". Achieving high efficiency and productivity at work, vocational school graduates must have the skills of work in accordance with the needs of the workforce. Work Skills, a skill that needs to be owned by individuals in the process of work, consists of hard skills and soft skills. Hard skills in vocational education are one among the skills that must be possessed by vocational students to achieve competence. [9], "There are some skills that are specific to needs in industry and manufacturing, the skills need will be very important as a defense to face of the information development 
and the environment rapidly". Hard skills are abilities related to something that can be learned in education aimed at improving intellectual ability. [7]," hard skills are technical or administrative procedures related to an organization's core of the business", [13], "Hard skills are skills where the rules stay the same regardless of which company, circumstance or people you work with.", While Soft skills are the abilities of each individual, cannot be seen, but the soft skills are the ability to which play a huge role in one's life, which strongly support someone's ability, career and job, [9; 7]. Appropriate soft skills play an important role in a successful career as well as during social interactions in the society. In addition, Reviews on these skills are highly sought after by employers recruiting fresh graduates ". [9; 26].

"Soft Skills are character traits, attitudes, and behaviors-rather than knowledge or technical aptitude. Soft skills are the intangible, nontechnical, personality-specific skills that determine one's strengths as a leader, facilitator, mediator, and negotiator". [7]," They have to do with how people relate to each other: communicating, listening, engaging in dialogue, giving feedback, cooperating as a team member, solving problems, contributing in conducted some first-rate training and was well meetings and resolving conflict". [6], in line state, that "the impact which the soft skills training could give in enhancing the output of hard skills". "Soft skills play a crucial role in making students employable as it enables them to be flexible, positive to change, handle everincreasing expectations of employers and to stay globally competitive". [17], proposes the structure of the future work in the industrial world will eliminate more jobs of nonskills, which will be replaced with jobs that require skills, a high expertise in the areas of reading, computation, communication, and problem-solving or reasoning skills.

Work Skills needed by industry is done Dacum needs analysis approach. This approach is used in a variety of methods to determine the accuracy of the use of learning and competency mapping by practitioners or specialists who have done the work and activities in accordance with the areas of expertise [9; 14]. The results of the analysis will show the gap between teachings and learn in a vocational school with work processes and activities in the industry. The gap found will be a basis for the development to improve the learning process through Lean-based learning model.

\section{Research Method}

Type of this research was descriptive quantitative, through DACUM (Developing a Curriculum) approach.[14;9]. The sample of this study was 100 respondents by using random sampling. It consisted of teachers of Mechanical Engineering Department, Practitioner 
of Machining Industry, and Expert/Lecturer of mechanical for the vocational high school of Mechanical Engineering. The research instrument used was a questionnaire that is based on the prepared blueprint in accordance with the needs of work skills of the vocational high school of Mechanical Engineering. The questionnaire used a Likert scale. Validity and reliability of research instrument used expert judgment that consisted of seven experts

\section{Result and Discussion}

The results of needs analysis of work skills are categorized into two parts: soft skills and hard skills for SMK students who are majoring mechanical engineering. For engineering needs of work skills in Mechanical Engineering of Vocational High school, it was used questionnaires which were filled out by respondents by using four categories of the scale options of Likert; very Important, Important, Less Important and Not Urgent. Response to work skills needed by using the questionnaire was determined through respondents' level of achievement. Decision criteria of the level of achievement of response were assigning a minimum of $50 \%$ of the total number of respondents' preferences through a questionnaire to the category selection agree and strongly agree. Based on the level of achievement of the indicator, there was elected as new recommendations for the establishment of indicators on soft skills and hard skills of students of vocational education in mechanical engineering. The results of the analysis are used in an attempt to build a new learning model of Lean-based learning model design for vocational high school students in an effort to improve work skills and competencies. The following is described further about respondents' level of achievement indicators and tables on recommended soft skills and hard skills.

\subsection{Soft skills}

Needs analysis of soft skills was categorized into two parts, namely general soft skills and specific soft skills in the field of machining jobs [9].General Soft skills category of machining jobs: 1).Demonstrating a willingness to develop a career, 68\%, and 32\%, 2). Showing ethics of communication, $80 \%$, and $20 \%$, 3). Showing the relationship among individuals, $76 \%$, and $24 \%$, 4).Showing good cooperation, $92 \%$, and $8 \%$, 5). Showing a high work ethic, $78 \%$, and $20 \%, 6$ ). Showing the action to solve the problem, $56 \%$, and $42 \%, 7)$. Maintaining a presence on time, $70 \%$, and $30 \%, 8)$. Indicating high initiative, $56 \%$, and $42 \%, 9$ ). Demonstrating honesty, $82 \%$, and $18 \%, 10$ ). Obeying all the rules work, 
$64 \%$, and $34 \%$, 11). Showing a responsible attitude, $84 \%$, and $16 \%, 12)$. Showing a good adaptation in working, 50\%, and 46\%.[9].

Special Soft skills in machining jobs: 1). Complying with the work process in accordance with the plans and design drawings, 68\%, and 26\%, 2). Adhering to the quotas for production, $56 \%$, and $38 \%, 3$ ). Showing the attitude of loyalty to the company, $66 \%$, and $30 \%$, 4). Motivated for training and teaching work processes, $58 \%$, and $42 \%, 5$ ). Showing the planning and operations according to the specifications of products, $46 \%$, and 50\%,6). Demonstrating Warming up the engine, 44\%, and 52\%, 7). Showing the readiness of operational equipment, $62 \%$, and $36 \%$, 8). Showing the check engine units, $64 \%$, and $36 \%$, 9). Setting the machine according to product specifications, $74 \%$, and $26 \%$, 10). Demonstrating material handling right, $52 \%$, and $44 \%$, 11). Demonstrating health and safety at work, $80 \%$, and $18 \%, 12$ ). Suggesting caution in operating the machinery, $74 \%$, and $26 \% 13$ ). Indicating maintenance and engine maintenance, $66 \%$, and $34 \%$, 14). Demonstrating checking the work according to standards of quality, $62 \%$, and $34 \%, 15$ ). Demonstrating off the machine according to the procedure, 78\%, and 20\%.[9].

\subsection{Hard skills}

1). Understanding and applying the rules engine drawing techniques and workmanship mark. 54\%, and 46\%. 2). Understanding and demonstrating basic concepts, the command functions of Computer Aided Design (CAD). 46\%, and 54\%. 3). Understanding and presenting a detailed picture making, etiquette of machine components with $C A D$ drawings in accordance with ISO. $42 \%$, and 56\%. 4). Analyzing and demonstrating the manufacture of engine components detailed images (projected images, image pieces and giving the size, tolerance, adjusting, a sign of craftsmanship and surface roughness value) with 2D/3D CAD. 48\%, and 50\%. 5). Understanding and identifying the parts lathe by its type and function. 48\%, and 46\%. 6). Understanding, analyzing and identifying the suitability of the cutting tool lathe machines. $24 \%$, and $70 \%$. 7). Implementing and presenting procedures of eccentric turning technique, $22 \%$, and $78 \%$. 8). Evaluating and determining the procedure for turning technique eccentric $34 \%$, and $60 \%$. 9). Analyzing and determining the making workpiece by using a faceplate, $20 \%$, and $74 \%$. 10). Implementing and making the technical procedure of making the workpiece assemblies, using various ways, $30 \%$, and $52 \%$. 11). Understanding and identifying parts of the milling machine based on the type and function, $36 \%$, and $56 \%$. 12). Analyzing and identifying the use of cutting tools on milling machines, $28 \%$, and $64 \%$. 13). Evaluating and using a milling machine cutting parameters for different types of work, $22 \%$, and $62 \%$. 14). 
Implementing and using the standard operating procedure of fraising technique in all forms of the workpiece, $38 \%$, and $58 \%$. 15). Understanding and identifying the grinding machines for various kinds of work, $34 \%$, and 56\%. 16). Implementing and operating engineering machining surface grinders for various types of work, $14 \%$, and $68 \%$. 17). Choose and use cutting parameters grinding machines for various kinds of work, $14 \%$, and 58\%. 18). Evaluating and using grinding machining techniques on various types of work, $10 \%$, and $78 \%$. 19). Understand and identify the parameters and parts on a lathe and $\mathrm{CNC}$ milling, 28\%, and 68\%. 20). Implementing and operating all the procedures at each work machining lathe and milling CNC, $24 \%$, and $72 \%$. 21). evaluating and repairing the failure of the work of a lathe and milling CNC, 32\%, and 62\%. 22). Analyzing and demonstrating Computer Aided Manufacturing (CAM) 2D and 3D for the process milling, lathe facing and drilling, $30 \%$, and $58 \%$. 23). Evaluating the use of CAM program through the simulation process on all machining jobs, $28 \%$, and $58 \%$. 24). Understanding the concept and adhere to the appropriate maintenance manual/surgery, $48 \%$, and $46 \%$. 25). Understanding the types, functions and demonstrating major maintenance tools mechanical and electrical, 30\%, and 68\%. 26). Understanding and classifying the types of disorders of the mechanical components of industrial machinery, $42 \%$, and $52 \%$. 27). Analyzing the damage and performing minor repairs industrial machinery mechanical components, 30\%, and 64\%. 28). Implementing and performing maintenance procedures / mechanical repair industry engine (compressor, pump, and motor gasoline), 46\%, and $46 \%$. 29). Analyzing and demonstrating preventive maintenance in the mechanical industry, $32 \%$, and $68 \%$. 30). Analyzing and showing the reactive maintenance (reactive maintenance) in industrial machinery, 26\%, and 64\%. 31). Implementing and demonstrating a final check of mechanical and electrical components in industrial machinery, 22\%, and 76\%. 32). Implementing and demonstrating management workshop manufacturing jobs, $20 \%$, and 54\%. 33). Analyzing disruption, damage and demonstrated improvements to components of pneumatic / hydraulic machinery industry, $26 \%$, and $74 \%$. 34). Understanding and demonstrating various types and concepts of fluid in the system of pneumatic / hydraulic to mechanical industry, 38\%, and 54\%. 35). Understanding the concept and demonstrating the working principles of electrical symbols and diagrams on a production machine, $30 \%$, and $66 \%$. 36). Analyzing and demonstrating the maintenance work/disruption in the electrical circuit system of machine tools/production, $32 \%$, and $62 \%$. 37). Implementing and practicing the principles of electro-pneumatic circuit maintenance and electro-hydraulic, $20 \%$, and $76 \%$. 38). Implementing and demonstrating the rules of drawing on machine construction drawing work, $44 \%$, and $52 \%$. 39). Analyzing and showing the results of analysis on engineering construction drawing 
machines, 24\%, and 70\%. 40). Evaluating and designing construction drawing machines with various types of connections, $20 \%$, and $70 \%$. 41). Analyzing and demonstrating the rules sign workmanship and price roughness on the picture detail of engine components, $18 \%$, and $68 \%$. 42). Applying and implementing rules engine component tolerances in the figure, $32 \%$, and $60 \%$.43). Evaluating the changes and modify the image of engine components and product assemblies, 30\%, and 56\%. 44). Understanding the types of types of production and implementing procedures in the process flow of the manufacturing industry, $28 \%$, and $70 \% .45)$. Implementing and measuring the performance of a production system in the manufacturing industry, $24 \%$, and $70 \%$. 46). Analyzing and planning the location and the standard of production in the manufacturing industry, $26 \%$, and $66 \%$.47). Analyzing and improve production results which were not effective and efficient (waste), 30\%, and 64\%. 48). Implementing and continuing improvement (continuous improvement) in the management of production, $62 \%$, and $34 \% .49)$. Understanding and applying in time production system in the manufacturing industry, 32\%, and 66\%. 50). Presenting and analyzing the design of an optimal control of production costs, $22 \%$, and $76 \%$. 51). Analyzing and managing the work environment according to the concept of production planning, $14 \%$, and $84 \%$. 52). Analyzing and processing data production forecasting total demand, $24 \%$, and $66 \%$. 53). Implementing and demonstrating the operation process map for manufacturing production, $24 \%$, and $70 \%$. 54). Applying and implementing procedures production process from beginning to end of production. (Materials, time, capacity), 32\%, and 68\%. 55). Implementing and understanding the concept, the basic procedure for warehouse control (in, out, quality), 34\%, and 64\%. 56). Processing and analyzing inventory balance, 30\%, and 58\%. 57). Implementing and analyzing the dismantling, removal and structuring effective and efficient goods, 32\%, and 62\%. 58). Understanding the classification and demonstrating the use of the equipment used in the warehouse (the main equipment, support), $22 \%$, and $74 \%$.59). Implementing and carrying out the process of care and maintenance equipment and supplies warehouse, 38\%, and 60\%. 60). Understanding and implementing procedures for distributing and structuring the concept of shortening the distance/channel of distribution of goods from producers to consumers, $30 \%$, and 64\%. 61). Understanding and carrying out the principle of distribution of goods based on the accuracy of the type and specifications of the products, the accuracy of the value of the product, the accuracy of the number of products, on time and delivery place, $50 \%$, and $48 \%$. 62). Applying the data recording of goods in warehouse equipment used along with the use of the information system of warehousing, $26 \%$, and $72 \%$. 63). 
Implementing and demonstrating the process of using the material handling warehousing information systems, 34\%, and 64\%. 64). Understanding and applying the basics and work safety system, $62 \%$, and $38 \%$.65). Understanding and implementing Safety procedures in all processes of machining work and industrial work processes, 78\%, and $22 \%$. 66). Analyzing and managing Resources hazards and potential hazards posed to the manufacturing of machining jobs, $72 \%$, and $28 \%$. 67). Applying and demonstrating tools safety standards according to the procedure in the manufacturing of machining jobs, $62 \%$, and $38 \%$.

\section{Conclusion}

Based on the research with needs analysis needs of work skills that have been done, there are 27 items of soft skills chosen by the respondent. Soft skills are divided into 2 parts; they are 12 indicators for general soft skills and 15 for special soft skills indicator. For hard skills, there are 67 items of indicators needed to support vocational competence in mechanical engineering. Thus, indicators of soft skills and hard skills have been chosen according to the needs of the industry or the world of work in the field of mechanical engineering, which will be components of vocational work skills. Then the work skills must be possessed and mastered by students majoring in Mechanical Engineering of SMK as one of the necessary competence. Based on the needs analysis of work skills, then it will be set as a resource to develop Lean-based learning model. This learning model will be developed systematically as learning process improvement efforts to improve the work skills of vocational students majoring in mechanical engineering of SMK.

\section{Acknowledgement}

We would like to thank those who have participated in helping and supporting the successful implementation of this research. Ministry of research and technology of higher education of the republic of indonesia (Kemenristek Dikti). Dean of teacher faculty, lecturers and staff within the Riau Kepulauan University,Indonesia. All research respondents and some parties can not be mentioned one by one. 


\section{References}

[1] Adrian, F. "The Psychology of Behaviour at Work". the individual in the organization (2nd ed.). New York: Psychology Press. (2005)

[2] Anna, at.al. "Lean production tools and decision latitude enable conditions for innovative learning in organizations": A multilevel analysis. Applied Ergonomics 47 (2015) 285e291. http://dx.doi.org/10.1016/j.apergo.2014.10.013.(2015).

[3] Blum. N. "Environmental education in Costa Rica": Building a framework for sustainable development?. International Journal of Educational Development 28 (2008) 348-358. doi:10.1016/j.jijedudev.2007.05.008. (2007)

[4] BPS. Badan Pusat Statistik. "Data Online Kependudukan dan industri kelautan". Bps.go.id.(2017)

[5] Calfrey C. Calhoun, A. V. F. "Vocational Education Concepts and operations". (D. Sipes, Ed.) (2nd ed.). California: Wadsworth.pp.60 (1982)

[6] Chaturvedi, et al."Communicative approach to soft \& hard skills". Journa IV SRDInternational of bussiness \& management research Vol 1 (1), 2011.Versi Elektronik http://www.vsrdjournals.com.(2011)

[7] Coates, E.D."Poeple Skill Training". Versi Elektronik, http://www.2020insight.net/ docs4/peopleskills.pdf. (2006)

[8] Galuh Setya. "Banyak Kegagalan Tes Karena Soft Skills". Versi Elektronik: http:// careernews.id/issues/view/1784.(2013).

[9] Hartanto, S., Lubis, S., \& Rizal, F. "Need And Analysis Of Soft Skills For Students Of The Mechanical Engineering Department Of Vocational", 12(30), https://doi.org/http: //dx.doi.org/10.21660/2017.30.TVET017. Pp.156-159 (2017)

[10] Liker, J., Meier, D. “The Toyota Way Field Book”: a Practical Guide for Implementing Toyota's 4Ps. McGraw-Hill, New York. (2006)

[11] Lonnie. W. "How To Implement Lean Manufacturing”. New York. Mc Graw Hill.(2010).

[12] Lubis. Syahron. "Concept and Implementation of Vocational Pedagogy In TVET Teacher Education".Versi Elektronik http://fptk.upi.edu/tvet-conference... Proceedings of the 1stUPI International Conference on Technical and Vocational Education and Training. Bandung, Indonesia, 10-11 November 2010.

[13] Mazoota.A.R."Workplace Soft Skills vs. Hard Skills" - Which are More Important?. Versi Elektronik accessed from http://www.armazzotta.com/, 22 February 2016

[14] Norton, R. E. “The DACUM Curriculum Development Process”, pp.1-9.(2004) 
[15] Palmer. R. "Skills for work: From skills development to decent livelihoods in Ghana's rural informal economy". International Journal of Educational Development 27 (2007) doi:10.1016/j.jjedudev.2006.10.003.pp 397-420. (2007).

[16] Proser's. C.A. dan Quigley, T.H. "Vocational education in a democracy, American Technical Society”. Chicago. Illinois. accessed from http://www.morgancc.edu/.../ prossers.(1949).

[17] Rani, E.M.S. "Need and importance of soft skills in the student". Vol,-II 3 JanuaryJuni(Summer) 2010. Associate Professor of English, Sri Sarada College for Women, Salem- 636016. Versi Elektronik, http://www.inflibnet.ac.in/ojs. (2010).

[18] Robert M.Gagne, Leslie J. Briggs, W. W. W. "Principles of instructional design (4th ed.). Florida: Holt, Rinehart and Winstgman.(1992)

[19] Robles.Marcel.M. "Executive Perception of the Top 10 Soft Skills Needed in Todays Workplace". Versi elektronik, Association for Business Communication Reprints and permission: http://www.sagepub.com. doi: 10.1177/1080569912460400 http://bcq. sagepub.com. (2012).

[20] Rogalski, S. A. "Vocational Education and Training in the United Kingdom". (2006)

[21] Rukun, K., Huda, A., \& Hartanto, S. (2015). "Designing Interactive Tutorial Compact Disc For Computer Network Subject”, 23(Cd), https://doi.org/http://dx.doi.org/10.11113/ jt.v77.6682. pp 21-26. (2015)

[22] Sousa.David.A. "Mind, Brain, and Education: The Impact of Educational Neuroscience on the Science of Teaching". Learning Landscape. Mind, Brain, and Education: Implication for Educators. Jurnal. Autumn 2011. Vol.5 No.1. Copyright. Learn.(2011).

[23] Syaiful Bahri Djamarah. “Strategi Belajar Mengajar”. Jakarta: Rineka Cipta.(1996)

[24] Undang-Undang Republik Indonesia Nomor 20. Tahun 2003 Tentang Sistem Pendidikan Nasional. Jakarta.Penerbit: BP Citra Jaya.

[25] William.M. Feld. "Lean Manufacturing. Tools, Techniques, And How To Use Them". New York: St Lucie Press (2001).

[26] Majid. S, Liming. Z et al. "Importance of Soft Skills for Education and Career Success". International Journal for Cross-Disciplinary Subjects in Education (IJCDSE), Special Issue Volume 2 Issue 2, 2012. Infonomics-society.org/IJCDSE (2012). 